\title{
Human capital information in management reports: An analysis of compliance with the characteristic of the relevance of disclosure
}

\author{
Ainhoa Saitua, Eneka Albizu, Lorea Andicoechea \\ Basque Country University (UPV/EHU) (Spain) \\ ainhoa.saitua@ehu.eus, eneka.albizu@ehu.eus, l.andicoechea@ehu.eus
}

Received July, 2014

Accepted April, 2015

\section{Abstract}

Purpose: The aim of this paper is to assess the compliance with the characteristic of the relevance of disclosure in Management Reports, particularly dealing with Human Capital (HC) information.

Design/methodology/approach: We codify all instances where narratives of IBEX-35 stock index companies over a five year period in Spain comply with the recommendations for a "high quality" Management Commentary (MC) in terms of the relevance characteristic of the information disclosed (IASB, 2005).

Findings: The analysis results show that a greater quantity of information about HC in terms of the number of pages devoted is not always indicative of higher quality in terms of relevance if we look for the application of IASB recommendations.

Research limitations/implications: Further research could assess compliance with other qualitative characteristics required by other standards or guidance that were internationally accepted.

Practical implications: Among the areas that require improvement in $\mathrm{HC}$ disclosures we highlight forward-looking information.

Social implications: We propose that an internationally accepted agreement must be struck to unite all the efforts that are being made to improve narrative information in the MC section, and specifically with reference to $\mathrm{HC}$. 
Originality/value: This work compiles the $\mathrm{HC}$ disclosures identified as best practices that may serve as a reference to other companies.

Keywords: Non-financial information, narrative disclosure, human capital, management report, IASB, management commentary

Jel Codes: M4

\section{Introduction}

Accounting narratives have grown in importance over the past 20 years (Jones \& Smith, 2014). They appear in the different sections of annual reports and represent opportunities for management to describe, discuss and evaluate the financial and non-financial performance of the company, setting the context for the financial statements. The section of the annual report that, depending on the country concerned, is known as the Management Report (MR), Management Discussion and Analysis (MD\&A), Operational and Financial Review (OFR), or Management Commentary (MC) as designed by the International Accounting Standards Board (IASB), provides information to place accounting results within a wider explanatory context that serves to communicate strategy and thereby attract investors (Ghani \& Haverty, 1998).

However, the way that companies prepare such reports does not always respond to user expectations, particularly in relation with company risks and uncertainties, the criticism being that there is a lack of useful disclosures (Kravet \& Muslu, 2013). Several authors argue that a change must be brought about, so that the disclosures offer a better explanation of the situation and performance of the business, but it is not clear how to get companies to disclose information that is relevant for users or to determine the corresponding regulatory approach that should be adopted (Springer, 1992; Hooks, Coy \& Davey, 2002; Stock, 2003; Linsley \& Shrives, 2006).

Meanwhile, in today's knowledge society it is a given that the most important assets in successful companies are in general their intangible assets (Sveiby, 1997), and in particular their Human Capital (HC). At this effect, this paper takes a general concept of Human Capital as defined by IIRC (2013). Every single aspect of a firm is determined by the skills and capabilities of its staff, in a way that influences the acquisition or generation of all the other intangible elements (Knauer, 2010; Gamerschlag \& Moeller, 2011). But information concerning personnel is disclosed haphazardly in different sections of the annual company report.

The Financial Statements and the Management Report (MR) section are mandatory in some national jurisdictions. Other reports are voluntary, such as the Sustainability Report or Social 
Responsibility Report. In any event, there is a lack of an internationally accepted framework as to where and how information should be submitted regarding human resources (Sujan \& Abeysekera, 2007; An, Davey \& Eggleton, 2011) and most of the content analysis research about intellectual capital (IC) disclosures has analyzed whole annual reports as a data source, even if they are not designed to convey IC information (Dumay \& Cai, 2014).

Existing research on textual analysis of corporate disclosures often devotes a significant amount of effort to developing the methodology ( $\mathrm{Li}, 2010$ ). In relation to the methods of analysis of narrative information disclosure, previous research, in general, measured the information with regard to the presence or absence of disclosure vis-à-vis a particular item by means of content analysis (Firth, 1979; Gray, Javad, Power \& Sinclair, 2001; Fontana \& Macagnan, 2013). This technique is considered particularly appropriate when the subject's language is crucial for the research (Holsti, 1969).

Volumetric analysis of the quantity (number of words, sentences, pages, etc.) of information devoted to each item has also been employed (Ax \& Marton, 2008; Tilling \& Tilt, 2010). Such investigations assume that frequency is an indication of the importance the company attributes to the item (Guthrie, Petty, Yongvanich \& Ricceri, 2004).

However, while financial and non-financial narrative information research has questioned whether a large number of sentences necessarily implies a high degree of transparency or information of greater quality or not, other developments (Beattie, McInnes \& Fearnley, 2002; Beattie, McInnes \& Fearnley, 2004; Schleicher \& Walker, 2010) have attempted to assess some characteristics of the information disclosed, such as its qualitative or quantitative nature, its positive, negative or neutral sign, and its historical or forward-looking orientation, among others. It is even argued that repetition in narratives may be used consciously as part of a communication strategy to emphasize the existence of intangible assets which are often inadequately recognized under the framework of traditional accounting (Davison, 2008).

On the whole, company practice is criticized because the narrative non-financial information provided in general, and particularly where HC are concerned, is far too qualitative (not based on quantitative data), historical (not presenting an appropriate focus on the future), and scarcely comparable, both over time and between companies (Kent \& Zunker, 2013; Chander \& Mehra, 2011).

But content analysis research is still an open debate. Loughran and McDonald (2015), for example, argue that a commonly used platform to assess the tone of business documents, Diction, is inappropriate for gauging the tone of financial disclosures, because about $83 \%$ of optimistic words and $70 \%$ of pessimistic words in an annual reports sample are likely 
misclassified. So, content analysis research about intellectual capital disclosures is also criticized on the grounds that as a research methodology it has a role to play in understanding the meaning of texts, but it needs to be innovative (Dumay \& Cai, 2014; Guthrie, 2014).

In Spain, in 2005 a new rule (Law 62/2003 on Fiscal, administrative and social measures) was implemented when transposing European directives, demanding information disclosure on $\mathrm{HC}$ in the MR where it was of relevance for understanding business trends. In this context, this work seeks primarily to assess the quality of the information disclosed by companies and to observe the trend in a longitudinal study, over the 5 years following the coming into force of the new law. Secondly, we try to advance in terms of the methods employed for analyzing disclosure quality, where compliance with the characteristic of relevance is concerned. With this objective we draw on the Management Commentary (MC) proposal from the International Accounting Standards Board (IASB), the main accounting standard setter at the international level. Finally, the outstanding contribution of this work lies in the usefulness of the best practices identified as a response to a suggestion in the Report on Accounting Reform in Spain (ICAC, 2002), due to the assistance they may provide to other companies when preparing an $\mathrm{MC}$ that complies with the requirements set forth in the guide.

Following the review in section 2 of the framework for information disclosure in the MR in general, and regarding $\mathrm{HC}$ in particular, section 3 furnishes the methodologies of analysis that have previously been in use, justifying the concrete proposal to be applied in this study. After the study in section 4 there is discussion of the results obtained, most of which constitutes a compilation of the best practices identified. Lastly, the conclusions are formulated, and some recommendations along future research lines are proposed.

\section{Human Capital information in Management Reports}

The competitive advantage of an organization resides in the resources and capabilities of internal origin that it manages and, especially, in human resources (Grant, 2004). Over time, the need for information on these resources has engendered diverse streams including Accounting for human assets (Hermanson, 1964) and the Intellectual Capital information practices (Johanson, 1996; Edvinsson and Malone, 1997; European Union, 2006; Dumay \& Rooney, 2011). Today, increasing weight is given to providing information on human capital $(\mathrm{HC})$, also within the context of Corporate Social Responsibility (CSR). Yet companies do not offer their interest groups detailed information on human resources, because they do not give proper credit to the value of such disclosure (Chander \& Mehra, 2011; Gamerschlag, 2013). 
In the general disclosure of financial and non-financial narrative information in the management report at an international level, evidence has been obtained pointing to a predomination of descriptive content, in the sense that there is a lack of quantified data, scarce use of indicators, and that historical information carries more weight than forwardlooking content (Beattie et al., 2004; Linsley \& Shrives, 2006; Carini, Veneziani, Bendotti \& Teodori, 2013).

In the area of Intellectual Capital (IC), when the objective was to measure the difference between market value and theoretical value (Edvinsson \& Malone, 1997; Sveiby, 1997), several proposals were formulated for drawing up IC reports (Meritum, 1998, 2002), etc. There is, however, no consensus regarding a standard model of measurement and information for IC (Bronzetti \& Veltri, 2013). Studying disclosure on innovation capital by 51 European companies, Bellora and Günther (2012) find that the information is mainly qualitative, not financial and historical, observing that the phenomenon appears to be European, rather than local. In this sense, we should anticipate that this can be the case also in Spain. With regard to information relating specifically to personnel, Kent and Zunker (2013) question the quality of employee information in a sample of Australian listed companies, having found evidence that even when companies have access to previous adverse publicity, they do not include voluntary negative information in the annual report.

In the branch of research that tries to explain the process called impression management, Merkl-Davies and Brennan (2011) criticize the narrow concept of economic rationality that underlies the predominant economics-based approach and introduce alternative concepts based on theories psychology/behavioral finance, sociology and critical perspectives which are rooted in different assumptions regarding the rationality and motivation of managers and organizational audiences to explain the impression management process.

All in all, a question that must be addressed (Wyatt \& Frick, 2010) is whether financial reporting applying accounting principles and rules, and accompanied by voluntary disclosure, helps stakeholders to adequately assess the efficiency of HC investment policies and practices in companies.

Having revised some critical evidence about different types of narratives in studies conducted in several countries (ICAC, 2002; Beattie et al., 2004; Linsley \& Shrives, 2006; Wyatt \& Frick, 2010; Carini et al., 2013; Kent \& Zunker, 2013), in this paper we suppose that HC disclosure in the MR of Spanish companies will be of poor quality in terms of the relevance of the disclosure. Whatever the case, the previous literature has devoted little study to the HC information in the MR in Spain since implementation of Law 62/2003, and certainly not with the aim of identifying 
best practices in terms of compliance with the characteristic of the relevance of such disclosure.

\section{Development of the methodological proposal for analyzing disclosures, construction of the sample and collection of information}

This study assesses the evolution of quality in terms of the relevance of HC disclosure in Management Reports (MR) during the first 5 years following the regulatory change in Spain. Taking into account the fact that Law 62/2003 does not make it mandatory to include HC information in the MR, but rather when it is of relevance for understanding the evolution of results and the economic situation, the study lies on the boundary between mandatory information and voluntary information. It must be added that the Management Commentary (MC) Discussion Paper (IASB, 2005) which we use as a reference for evaluating the quality of information disclosed is also of voluntary application, as is also the case with the final document Practice Statement MC (IASB, 2010). This disclosure analysis focuses on the MR in order to assess the informative behavior of companies with regard to this document which, although it ought to be useful for offering a business view from the administrators' viewpoint, has in practice in Spain revealed problems connected with information quality, thereby reducing its usefulness (ICAC, 2002).

When the impact of a regulation on disclosure is analyzed (Beretta \& Bozzolan, 2004), it is necessary to consider the way in which managers go about choosing the level of disclosure to adopt (Bushee, 2004). In this regard, since there has been evidence over recent years of positive trends in the quantity and quality of employee information and social information in Spain (Archel, 2003; Aranguren \& Ochoa, 2008), we set out from the general hypothesis that, for the first 5 years following the coming into force of Law62/2003 (period 2005-2009), HC information quality in the MR will be low, but will have witnessed improvement. Our supposition is rooted in the existence of various phenomena. On the one hand, we assume that when the Law came into effect there would have been an increase in the amount of $\mathrm{HC}$ information in the MR, which some companies already incorporated voluntarily. On the other hand, publication of the Discussion Paper (DP) MC (IASB, 2005) might have influenced the gradual increase in the quality of such disclosures, in that the information they included would be more relevant in line with its recommendations.

The project team that developed this DP-MC considered that it was inappropriate to specify the exact information that should be revealed in the MC, or the way it should be presented. Instead, the requirements for a MC ought to establish the essential areas of content needed so 
that the information would be useful for users, and the principles and qualitative characteristics that information disclosed by companies should meet (IASB, 2005).

To meet the objective of the MC, an entity should report on five areas:

- the nature of its business,

- its objectives and strategies,

- its key resources, risks and relationships,

- its results and perspectives,

- its performance measures and indicators.

Out of five content areas proposed, we concentrate on that of "Key Resources, Risks and Relationships". Some examples that IASB mentioned include processes, systems, distribution networks, rights over natural resources, reputation, and human and intellectual capital.

The qualitative characteristics that the IASB stipulates should be demanded of information disclosed in an MC, include understandability, relevance, balance and comparability over time, among others. Although it is clear that we will not have enough information to ensure that a company really considers an item as relevant or not, we focus our attention on the characteristic of the relevance of the information disclosed by companies. First, because we think it is the most important characteristic in order to guarantee utility need to users, and also in accordance with the new Spanish 62/2003 disclosure regulation that solicits information to the extent that it is relevant to an understanding of the business.

The IASB, in its conceptual framework for financial information, considers as relevant information that which is capable of influencing the decisions made by users. In the same regard, what the work group highlighted for the Management Commentary is disclosure concerning "Resources, Risks and Relationships" contents should be limited to those that are key. In this context, the intention is not that an enterprise should offer a list of all its resources, risks and relationships, but that it identify those that are critical for implementing their strategy and achieving their targets (IASB, 2005).

To evaluate the degree of compliance of the qualitative characteristic of narrative disclosures (as Botosan (2004) suggests should be done), in this case, focusing on relevance, we use some comparative lists based on the requirements proposed by the IASB (2005) that could be used for all types of information contents (any "resource, risk or relationship" of a company), although in this study we only analyze content associated with HC. Concretely, we focused on 
the workforce, including references to intellectual capital that might appear in connection with knowledge acquired, managed, or otherwise, by staff.

Thus, as it is possible that the concept of quality of disclosure is incommensurable (Botosan, 2004), our research does not seek to assess the quality of disclosure in absolute terms by calculating an overall index for each company in the traditional manner charting the absence or presence of a certain thematic content, but identifies the most committed disclosure behaviors with the relevance of the information provided in each case, in order to identify those we consider the best practices.

When the text units (sentences) disclosing different items related with $\mathrm{HC}$ have been identified, compliance with the qualitative characteristic of relevance is assessed: if the statement identifies $\mathrm{HC}$ as a key resource, if it discusses the appropriateness in the way company objectives are met, whether it explains how the issue is being managed, etc. We proceed in the same way when addressing HC information as a key risk or key relationship, applying the corresponding questions (Table 1 ). Then we count the number of occasions when a company offers a disclosure that can be coded as responding to each of the questions provided for assessing the relevance of the disclosure.

\begin{tabular}{|c|l|}
\hline QRE & \multicolumn{1}{|c|}{ Questions for information gathering on HC as a key RESOURCE } \\
\hline QRE1 & Does the Management Commentary identify it as a key resource? \\
\hline QRE2 & $\begin{array}{l}\text { Does it discuss the appropriateness of the resource for meeting company } \\
\text { objectives? }\end{array}$ \\
\hline QRE3 & Does it explain how the issue is being managed? \\
\hline QRE4 & $\begin{array}{l}\text { Does it contain a management explanation as to how they aim to manage the } \\
\text { issue? }\end{array}$ \\
\hline QRE5 & $\begin{array}{l}\text { Does it include an analysis of plans to tackle any deficiency or surplus of resources } \\
\text { that is identified? }\end{array}$ \\
\hline QRI & \multicolumn{1}{|c|}{ Questions for information gathering on HC as a key RISK } \\
\hline QRI1 & Does the Management Commentary report on the degree of relevance of risk? \\
\hline QRI2 & Does it present a statement of distinction between key risk and subsidiary risk? \\
\hline QRI3 & Is it a key risk? \\
\hline QRI4 & $\begin{array}{l}\text { Does it provide contextual information to enable an understanding as to why the } \\
\text { issue is considered a key risk? }\end{array}$ \\
\hline QRI5 & Is it a subsidiary risk? \\
\hline QRI6 & $\begin{array}{l}\text { Does it contain a management explanation as to how they aim to manage the } \\
\text { issue? }\end{array}$ \\
\hline QRI7 & $\begin{array}{l}\text { Has it identified this as a key opportunity that may affect the company's ability to } \\
\text { meet its objectives? }\end{array}$ \\
\hline QRI8 & Does it indicate that the company's ability to meet its objectives may be affected? \\
\hline QRI9 & Has the Commentary explained its potential impact? \\
\hline QRL & Questions for information gathering on HC as a key RELATIONSHIP \\
\hline QRL1 & Does the Management Commentary identify this as a key relation? \\
\hline QRL2 & Does it include information on how company performance may be affected? \\
\hline QRL3 & Does it include information on how company value may be affected? \\
\hline QRL4 & Does it explain how the issue is being managed? \\
\hline QRL5 & $\begin{array}{l}\text { Does it contain a management explanation as to how they aim to manage this } \\
\text { issue? }\end{array}$ \\
\hline
\end{tabular}

Table 1. Questions to assess the relevance of the information relating to HC. IASB (2005) for a MC 
Consideration has been given only to companies that belonged to the IBEX-35 stock index throughout the entire period under study (Pierrot \& Spring, 2010), because they are characterized by greater visibility in the capital market and are, in consequence, expected to act as leaders in relation to other companies. Once firms that did not belong to the index during the entire period (12 businesses) had been excluded, the final sample comprises 23 companies, six of which stand out (Telefonica, Santander, BBVA, Iberdrola, Repsol YPF and Inditex) because they account for $75 \%$ of the capitalization of the IBEX-35 stock index at the date when the study was designed (at 1 September 2010) and their position is far ahead of the seventh company.

\section{Results of the empirical study}

In coherence with the results obtained by Too and Somasundaram (2011) for information on intellectual capital, in our case, the total number of pages that contain some HC information for the set of companies analyzed rises from 53 pages in 2005 to 76 in 2009 (Table 2).

\begin{tabular}{|c|r|r|r|r|r|r|r|r|r|r|}
\cline { 2 - 12 } \multicolumn{1}{c|}{} & \multicolumn{2}{c|}{$\mathbf{2 0 0 5}$} & \multicolumn{2}{c|}{$\mathbf{2 0 0 6}$} & \multicolumn{2}{c|}{$\mathbf{2 0 0 7}$} & \multicolumn{2}{c|}{$\mathbf{2 0 0 8}$} & \multicolumn{2}{c|}{2009} \\
\cline { 2 - 12 } & \multicolumn{1}{c|}{ TL } & HCL & \multicolumn{1}{c|}{ TL } & HCL & \multicolumn{1}{c|}{ TL } & HCL & \multicolumn{1}{c|}{ TL } & HCL & \multicolumn{1}{c|}{ TL } & HCL \\
\hline $\begin{array}{c}\text { N. } \\
\text { pages }\end{array}$ & 494 & 53 & 602 & 71 & 681 & 72 & 775 & 79 & 786 & 76 \\
\hline \% & $100 \%$ & $10.73 \%$ & $100 \%$ & $11.79 \%$ & $100 \%$ & $10.57 \%$ & $100 \%$ & $10,19 \%$ & $100 \%$ & $9.67 \%$ \\
\hline Media & 21.48 & 2.30 & 26.17 & 3.09 & 29.61 & 3.13 & 33.70 & 3.43 & 34.17 & 330 \\
\hline Max. & 64 & 18 & 67 & 19 & 68 & 18 & 90 & 19 & 125 & 15 \\
\hline Min. & 2 & 0 & 3 & 0 & 3 & 0 & 7 & 0 & 5 & 0 \\
\hline
\end{tabular}

Table 2. Number of pages in total Management Report (Total length-TL) and number of pages including some $\mathrm{HC}$ information ( $\mathrm{HCL})$, for all companies

However, this development does not correspond with the general increase in the total length of the $M R$, because it is only a matter of a $43 \%$ increase against $59 \%$, which stands in relative terms as a percentage reduction (from $10.73 \%$ of the total of the MR in 2005 to $9.67 \%$ in 2009). Meanwhile, the length averages conceal a great diversity of practices between companies. Taking the overall MR, the companies' individual values increase from a minimum of 2 pages and a maximum of 64 (in 2005), to a minimum of 5 and a maximum of 125 (in 2009). But there are companies that disclose nothing about HC in each year analyzed, although there are increasing numbers of companies that report something for this content in the Management Report (the enterprises that disclose no HC information in the MR fall from 9 companies in 2005 to 4 in 2009). 


\subsection{Compliance with the qualitative characteristic of relevance}

Although it may seem surprising, we did not find any information rating $\mathrm{HC}$ as a key relationship. This might be due to the fact that the nature of the staff as a 'relationship' is not grounded in the academic literature or in the collective social mindset. This is the reason why we only carried out the analysis of compliance with the qualitative characteristics of disclosure that presents the workforce as a resource and as a risk.

\subsubsection{Relevance of information disclosed on HC taken as a key resource}

We found only 3 observations that identify the labor force as a key resource (QRE1) in their MR for 2008, and 2 for 2009, with a total of 4 companies involved. In relation with the second question (QRE2: Does it discuss the appropriateness of the resource for meeting company objectives?) a greater number of observations are made (maximum of 8 in 2008), corresponding to a total of 7 companies.

Analysis of the third question (Does it explain how the issue is being managed?) was broken down into two. The observations that provide a "general" explanation of how the issue is being managed (QRE3.1) show a higher percentage of compliance (in 2009, 44\% of the companies that disclosed some information about the workforce for that year reported, thereby meeting this characteristic in some way). And for the observations that respond in terms of how the issue is being managed in more "partial" or "specific" terms (QRE3.2), in that they itemize some of the areas or policies that typify human resources management, altogether a total of 11 companies are identified.

The questions QRE4-Does it contain a management explanation as to how they aim to manage this issue? and QRE5-Does it include an analysis of plans to tackle any deficiency or surplus of resources that is identified?, which have a clear focus on the future, did not give rise to any observation. This corroborates our supposition that $\mathrm{HC}$ disclosure in the MR would be of poor quality in terms of the relevance of the disclosure if we test it out against the recommendations of the IASB guide (2005).

Taking the sum of the values recorded for the 5 QRE-questions (one of them broken down into two), we can assert that compliance with the qualitative characteristic of relevance shows a positive trend, rising from 11 to 41 observations (a $273 \%$ increase). For companies committed in this regard an increase can also be discerned (from $36 \%$ of those that disclosed HC information to some degree in 2005 , to $72 \%$ in 2009). This development would warrant a positive assessment from the point of view of the user and the regulatory body and, 
consequently, from the social standpoint. Nevertheless, a great deal of work remains to be done before, firstly, all the companies reveal some information about HC and, then, for their disclosures to meet the characteristic of relevance for all the years they report on.

With regard to the number of times that a disclosure was given in reply to the question QRE3.2 "How, specifically, is the issue being managed?", in a similar way to the approach adopted by Kent and Zunker (2013) who find information on topics such as safety and health, career, family, education, employee stock plans or agreements on jobs, etc., we not only derived our HR policy list from the previous literature (Archel, 2003), but also took into account the observations found in the study. Thus, we created several information categories, based primarily on what are known as policies of human resources management.

For the period analyzed an overall increase of $225 \%$ is shown, a trend that we could describe as positive. Whatever the case, the number of observations concerning HC management policies is far higher. However, the values for each item still seem low, and each type of information analyzed presents its own trend. Overall, the policies that produce most observations were those for Training (17), Development (13) and Recruitment (12) (Table 3).

\begin{tabular}{|c|c|c|c|c|c|c|c|c|}
\hline & $\begin{array}{l}\text { Human resources } \\
\text { management policies }\end{array}$ & 2005 & 2006 & 2007 & 2008 & 2009 & $\begin{array}{c}\text { Total } \\
\text { observ. } \\
\text { comp/year }\end{array}$ & $\begin{array}{c}\text { Evolution } \\
\text { (2005- } \\
2009)\end{array}$ \\
\hline 1 & Recruitment & 1 & 1 & 2 & 4 & 4 & 12 & $300 \%$ \\
\hline 2 & Equal opportunities & 0 & 1 & 1 & 1 & 3 & 6 & $100 \%$ \\
\hline 3 & $\begin{array}{l}\text { Reconciliation of family } \\
\text { and professional life }\end{array}$ & 0 & 1 & 2 & 1 & 1 & 5 & $100 \%$ \\
\hline 4 & $\begin{array}{l}\text { Occupational health } \\
\text { and safety }\end{array}$ & 2 & 1 & 2 & 1 & 3 & 9 & $50 \%$ \\
\hline 5 & Training & 2 & 4 & 3 & 4 & 4 & 17 & $100 \%$ \\
\hline 6 & Development & 2 & 2 & 3 & 3 & 3 & 13 & $50 \%$ \\
\hline 7 & $\begin{array}{l}\text { Intellectual Capital } \\
\text { Management }\end{array}$ & 0 & 1 & 0 & 1 & 1 & 3 & $100 \%$ \\
\hline 8 & Communication & 0 & 1 & 2 & 0 & 1 & 4 & $100 \%$ \\
\hline 9 & $\begin{array}{l}\text { Labor relations and } \\
\text { conflict }\end{array}$ & 0 & 1 & 1 & 2 & 1 & 5 & $100 \%$ \\
\hline 10 & $\begin{array}{l}\text { Collective bargaining } \\
\text { agreements }\end{array}$ & 1 & 2 & 3 & 2 & 1 & 9 & $0 \%$ \\
\hline 11 & $\begin{array}{l}\text { Remuneration (share } \\
\text { option plans...) }\end{array}$ & 0 & 0 & 3 & 2 & 2 & 7 & $100 \%$ \\
\hline 12 & Other benefits & 0 & 0 & 0 & 1 & 0 & 1 & $0 \%$ \\
\hline 13 & $\begin{array}{l}\text { Organizational } \\
\text { structure }\end{array}$ & 0 & 0 & 0 & 0 & 2 & 2 & $100 \%$ \\
\hline \multicolumn{2}{|c|}{ Total observations } & 8 & 15 & 22 & 22 & 26 & 93 & $225 \%$ \\
\hline
\end{tabular}

Table 3. Annual values of codification regarding "How are they being managed" for specific policies (QRE3.2), and evolution 
Compared with the results obtained by Pascual, Moneva and Fuertes (2001), to the effect that for 15 companies in the Spanish electrical sector for the year 1997, 12 included content concerning recognition of the merits or capabilities of their own employees within the Annual Report, although only one of them did so in the MR, in our study, out of 23 companies we only found 6 observations of this kind in the MRs for the 5 years analyzed.

\subsubsection{Relevance of information disclosed on HC taken as key risk}

Only 21 observations were found that report on personnel as risk, corresponding to 5 companies. The majority ( 3 companies) refer generically to the possibility of the existence of "human failures" or "human errors" in a list that contains other operational risks such as technical failures, etc., but some other references to "other risks" associated with personnel: "Other risks that group $X$ are exposed to are: (...) risks related with the prevention of risks at work (...)". And there is just one company that includes the definition of risk as stipulated in the regulation that it must apply: "Group $Y$ has adopted as the definition of operational risks that which the New Basle Accord established, the risk of loss resulting from inadequate or failed internal processes, people and systems or from external events (...)". Therefore, while over the period analyzed a slight increase is detected (rising from 1 company to 5), in general, $78.2 \%$ of the companies did not disclose information in the MR on personnel considered as a risk.

For compliance with the characteristic of relevance, in the case of information on risks the IASB document (2005) laid greatest emphasis on the explanations that should be given. Accordingly, we can break down the specific nine QRI questions (Table 1) into three categories,

- information on the degree of relevance of the risk (QRI1-5);

- information on its possible impact (QRI7-9); and

- information on planning how to manage it (QRI6).

Fulfillment of the qualitative characteristic of the relevance of the information on the labor force taken as risk is very scarce, as only two questions appear to which we could assign a value (Table 4): QRI8-Does it indicate that the company's ability to meet its objectives may be affected?, and, QRI6-Does it contain a management explanation as to how they aim to manage this issue? As a positive remark we observe that the percentage of firms that make a commitment to compliance, in relation to the number of companies that make some disclosure in this regard, is very high, reaching $100 \%$ in 2008 and 2009. 


\begin{tabular}{|c|c|c|c|c|c|}
\hline & 2005 & 2006 & 2007 & 2008 & 2009 \\
\hline $\begin{array}{l}\text { Number of companies that present some disclosure on risk in } \\
\text { relation with HC }\end{array}$ & 1 & 4 & 4 & 5 & 5 \\
\hline $\begin{array}{l}\text { Number of observations: QRI8-Does it indicate that the } \\
\text { company's ability to meet its objectives may be affected? }\end{array}$ & 0 & 2 & 2 & 2 & 3 \\
\hline $\begin{array}{l}\text { Number of observations: QRI7- Does it contain a } \\
\text { management explanation as to how they aim to manage this } \\
\text { issue? }\end{array}$ & 0 & 3 & 3 & 5 & 5 \\
\hline $\begin{array}{l}\text { Number of companies committed to compliance with } \\
\text { characteristics of information as risk }\end{array}$ & 0 & 3 & 3 & 5 & 5 \\
\hline $\begin{array}{l}\text { Percentage of companies that, having disclosed } \mathrm{HC} \text { as risk, } \\
\text { committed themselves to compliance with the characteristic } \\
\text { of relevance }\end{array}$ & $0 \%$ & $75 \%$ & $75 \%$ & $100 \%$ & $100 \%$ \\
\hline
\end{tabular}

Table 4. Annual values of codification regarding compliance with the qualitative characteristic of the relevance of information about $\mathrm{HC}$ as risk

So, in general, companies do not provide information on HC understood to constitute a risk. While it is true that they are under no obligation to do so provided that they do not deem the matter to be relevant, following the IASB recommendation (2005) that if a company considers that it runs certain risks in relation to its staff, it should include more information than that disclosed for the period analyzed.

\subsection{Compilation of best practices}

Corresponding to each question put for the characteristic of relevance, some of the observations selected for best practices run as follows:

\subsubsection{QRE1-Does the Management Commentary identify it as a key resource?}

In this case we collected all the observations where a firm refers to its $\mathrm{HC}$ (as a resource, as employees' skills or even the management of such resources) as "key", "basic pillar", "factor", etc. :

BKT2008, p.46: "The professionalism and proximity of its managers... are the keys that explain why Bankinter's Equity Services constitute a new milestone in customer service for Personal Finances".

ELE2008, p.29: "One of the basic pillars of Endesa's strategy is the management of intellectual capital and talent, aimed at integrating and coordinating the knowledge learning and 
management of all the people who work in the Company, overcoming geographical, organizational and cultural barriers".

ENG2008, p.68: "Enagás considers the social dimension a strategic management factor...".

ELE2009, p.26: "Another of the basic pillars of Endesa's R\&D\&I strategy is the management of intellectual capital and technological talent, in order to integrate and coordinate the technical knowledge learning and management of all the people who work in the Company...".

FER2009, p.29: "Human resources policies are a key element of Ferrovial's commitments within the area of corporate responsibility...".

4.2.2. QRE2 - Does it discuss the appropriateness of the resource for meeting company objectives?

In this section we have selected some of the observations where the firm establishes some cause-effect relation regarding some aspect of its $\mathrm{HC}$, achieving general results for the business, whether these be monetary or non-monetary achievements.

ELE2006, p.15: "Personnel costs... include... provision allocations $\ldots$ and for the signing of a new employment regulation plan within the framework of the Mining Plan, which will in turn facilitate part of the reduction of costs foreseen in the company's strategic objectives".

IBLA2006, p.10: "To reduce unit operating costs, we highlight the following initiatives: in the ground staff collective agreement, whose annual cost represents approximately $55 \%$ of IBERIA's total staff costs, a wage freeze was agreed and a new non-consolidable results-based participation scheme for the years 2005 and 2006...".

IBLA2007, p.49: "The unit staff cost (Available Seat Kilometers - ASK) dropped by 2.0\%, thereby accomplishing one of the fundamental objectives defined in the 2006/2008 management plan".

REP2008, p.59: "In 2008 more than 1,850 people joined the company. More than 120 of the new recruits are associated with what is termed the emergency plan, a program that lasts for five years and which aims at the incorporation of professionals in the Upstream area in order to respond to the growth plan of this business. Likewise, they emphasize the more than 280 new members taken on in Downstream, in the area of Refine Spain, for staffing the installation extension projects and guaranteeing the necessary generational replacement". 


\subsubsection{QRE3 - Does it explain how the issue is being managed?}

With reference to the specification of concrete HR policies (QRE3.2), from the observations received, in general, we selected those that seemed the most interesting from the last financial year available:

\section{- Recruitment}

REP2009, p.96: "The year 2009 stood out for the reinforcement of actions aimed at implementing selection techniques and devising recruitment attraction actions from a job marketing perspective. The company is basically fuelled by young talent, interested in making the most of the career opportunities that Repsol YPF can provide. Nearly $80 \%$ of recruits to the company in 2009 were under 35 years old, and one of the objectives was to increase the spread of company values as an element of attraction. To this end, the organization reinforced its presence in the University through its participation in job forums (10 face-to-face and two online). It has also continued to support the "Impulsa" Scholarship Program, aimed at students in the last years of their degree... in addition, in 2009 the job channel at repsol.com was consolidated among users seeking work, with an average of 2000 accesses and queries for each offer".

\section{- Equal opportunities}

REP2009, p. 93: "Diversity, equal opportunities and conciliation. In 2009, Repsol's Diversity and Conciliation Committee decided to keep on developing the existing... different skills programs, and promote their application in all the countries where the company operates, matching them to the needs of the milieu. In addition, new projects associated with ... were initiated. In 2009 Repsol signed the Diversity Charter, with which the company is publicly committed to foster the fundamental principles of equality; behavior that respects the right of all people to inclusion in the job environment and society, regardless of their diverse profiles; recognition of the benefits provided by the inclusion of cultural, demographic and social diversity, in its organization; the implementation of concrete policies that favor a working environment free of prejudices in the areas of employment, training and promotion, as well as encouraging programs to combat discrimination against disadvantaged groups. ... Among the most important initiatives undertaken in 2009 stands the edition of the White Paper on Recruiting Disabled People... This is the first publication of this kind drawn up by a company in Europe, and is in keeping with the company's values and its commitment to society... after the success of the project in Spain, efforts have been directed at extending this policy to all the countries where the company operates. On 31 December 2009, the total number of workers with disabilities was 544...". 
TL52009, p.91: "...Increasing the number of women directors, which reflects the commitment of the chain to gender equality".

- Conciliation of working and family life

SAN2007, p.16: "In parallel with these corporate policies, Santander makes a continual effort at a corporate and local level to support a balance between professional and personal life by means of different initiatives such as the Equality Plan, signed in 2007 in Spain, the Children's Education Center for the children of employees of the Ciudad Grupo Santander or with nursery vouchers in Spain, Flexible Working policy in the United Kingdom, the Libra program in Portugal, the Voce program for quality of life in Brazil and the Work and Family program in Chile, among others".

REP2009, p.95: "Repsol YPF continues to drive conciliation measures, since it is a company that assesses, promotes and facilitates a balance between the personal and professional life of its employees. In 2009 this approach was reinforced, incorporating the promotion of conciliation into the company's management style and encouraging the role of department heads as drivers of change, serving as an example for their teams. The company has broadened and improved its conciliation measures in different countries, adapting them to the legislative and social environment, with the objective of making available to employees a range of options that favor conciliation in the day to day and in special situations, with the desired flexibility. After the good results of the pilot test carried out in 2008, the Telework Program, which was developed in 2009 in various stages, included at the end of the financial year 362 employees in Spain, 140 in Argentina and 14 in Portugal. ... 48\% of them were aged between 35 and 44, and the modalities most used were those of one or two days a week".

- Health and safety at work

REP2009, p. 98: "In 2009 a homogeneous set of regulations was still being developed for the whole group. The Individual health Monitoring procedure was completed with the Advisory Guide for Periodic Health Monitoring in the Repsol group, which contains 17 action protocols. And the Technical Health Committee passed the Action Guide against the Influenza A (H1N1) Pandemic, which was followed by an employee information campaign, whilst hygienic preventive measures were implemented. Similarly, an internal auditing program was launched to assess the degree of compliance with the internal regulations on health at work, which produced satisfactory results in terms of the level of knowledge and degree of compliance with the rules". 
- Training

BKT2009, p.5: "Specific training programs have been renewed and boosted, matching them to the demands of the new MIFID regulation, with several internal courses being provided for the whole workforce".

SAN2009, p.22: "The corporate training and knowledge center El Solaruco, situated in the headquarters of... develops ongoing activity for the training and development of banking professionals. Some examples are: the first edition of the Corporate Development Program...; within the curriculum management plan, 779 managers received 14,892 training hours, and different high potential development programs covered a total of 18,712 training hours during 2009. The on-line training platform Santander learning continues to be implemented in different companies and countries where the group operates. The on-line catalogue, which is freely available to employees, was reinforced in the second half of the year with 45 new courses on managing, financial and associated skills...".

- Development

REP2009, p. 97: "Repsol YPF combines the need as an organization to have the right competencies and skills, and to acquire through planning those that it will need in the future, with a commitment to offer attractive opportunities of professional development to the people who make up the company. Its policies and programs of training, mobility, evaluation, etc., make it possible to manage people's career paths into the organization in an integrated fashion, guaranteeing the equal opportunities of all employees, regardless of their origin, gender, or age... Internal mobility at Repsol is designed as an opportunity for the professional development of the employees. In 2009 the horizontal approach was given more reinforcement, through the management of talent pools, mobility round tables and proactive searches, which has made it possible to produce a total of 5,316 mobility transfers during the financial year. In the area of promotions and appointments, 2,549 people had their personal classification altered in $2009(1,849$ promotions and 700 appointments). Other outstanding actions in 2009, geared toward detecting talent and favoring employee development, are the refinement of a new tool for the People Review system...; the Development Center program...; continuity of the technical competencies and training itineraries program...; launching of a process for defining individual development programs and a proposal for the recognition of qualifications". 
- Intellectual capital management

REP2009, p. 99: "Repsol YPF is currently immersed in a moment of change and adaptation... In 2009 new communities of practice were still being created which along with those already in existence, comprise some 22,000 people in the whole company. It also proceeded with projects of employee knowledge retention and its transfer to others. The methodology applied is rooted fundamentally in the compilation of personal stories which are recorded using audiovisual media".

- Communication

SAN2007, p. 16: "Santander also keeps open a variety of communication channels with its professionals through intranets, publications, systems for gathering ideas and suggestions, employee portals, employee support hotlines, etc.".

BBVA2009, p.36: "Blogosphere... multidirectional internal online communication tool that facilitates the exchange of individual knowledge and turns it into collective knowledge; the new Global Directory that contributes all the functionalities of web 2.0 in a single information site for all the employees in the BBVA Group".

- Labor relations and disputes

REP2008, p. 63: "In 2008 the period of the 4th framework agreement for Spain drew to a close without any labor disputes".

IBLA2009, p.31: "The number of labor hours..., despite the fact that the financial year of 2009 was diversely affected by a greater number of incidents (cancellations and delays due to days of industrial action by crew members,...$)$ ".

- Collective bargaining agreements

ACX2007, p.28: "In March 2008 an agreement affecting 2,225 workers that had been under negotiation since January was signed, representing an important step in social and labor stability for the period 2008 to 2012".

REP2008, p.63: "In November negotiation of the 5th framework agreement began, with the constitution of the negotiating table and the presentation of the negotiation platforms. In the first half of 2008 the Harassment Protocol was signed, establishing the steps any employee should follow in the case of being harassed at work".

- Remunerations, including options or share plans for employees

SAN2007, p.15: "Santander has a policy of total compensation aimed at maximizing the attraction and retention of talent, optimizing the remuneration of professionals, reinforcing corporate culture, strengthening managers' commitment to the group, and 
utilizing economies of scale.... It encompasses different concepts that constitute total compensation, comprising a fixed retribution, a variable retribution and some social benefits. Since 2007, the manager's total compensation scheme also includes the Long Term incentives policy, approved at the General Meeting of Shareholders. Likewise, on the occasion of the 150th anniversary of Santander, the General Meeting of Shareholders approved delivery of 100 shares to all the professionals in the group in recognition of their contribution, effort and commitment".

- Other benefits including housing,,..

REP2008, p.57: "Another of the outstanding measures was the pilot employee service support project through an outside company that offers very varied services, ranging from legal and financial advice to the selection of domestic staff".

- Organizational structure of HR

REP2009, p.92: "In February 2009, the Management Board passed a series of changes at the first management level in the company, aimed at simplifying and concentrating the management team, favoring coordination between the strategic businesses of Repsol and improving the efficiency of management processes. The main changes were: reduction of three general managements,... creation of the General Management of People and Organization, which replaces the previous General Human Resources Management, and includes Corporate Management of Managerial Development and Information Systems Management".

\subsection{Discussion of the results}

Our results agree in part with those of Chander and Mehra (2011). For a sample of companies in India they find a low level of disclosure of intangible assets but improving from 2003-4 to 2007-8, the most disclosed items being those mandatory and those showing greater competitive advantage. The authors attribute the unorganized and unsystematic disclosures to a lack of appropriate framework for disclosing intangible assets in the annual reports. In an attempt to overcome this limitation, we have presented a selection of the narratives we found most interesting from the compilation of all the best practices. This selection may act as a guide to other companies.

Nevertheless, among the areas that require improvement, in agreement with Schleicher and Walker (2010) who suggest the need to reconsider the unregulated nature of forward-looking narratives, we highlight forward-looking information related to $\mathrm{HC}$, as we did not find any 
observation referring to a management explanation of their intentions to manage this particular issue, nor did we detect any analysis of plans to tackle any deficiency or surplus of resources identified in this regard that might be of help to users when assessing a company's future management capacity.

Approximately half the companies analyzed disclose some information about the number of employees. However, the evolution shows two trends: an initial increasing tendency (20052007) and a later one of decrease (2007-2009), with the result that the number of companies that disclose information for the number of employees in 2009 is the same as that for 2005. In a similar way to the results that demonstrate a decrease in social and environmental disclosures in parallel with the deepening of the economic recession in France (Tower, Pignatel, Hahn, Raja \& Raja, 2010), this reduction in disclosures concerning the number of employees may also be due to the economic recession that began in 2008 in Spain.

When we turn to information on staff impact on the balance sheet and profit and loss account, it is also very thin on the ground. In the case of employee income, there is only one company that offers information for various years. For productivity there is a maximum of 2 companies that report in 2008, and for provisions for pensions, etc., the highest number of companies disclosing information is 3 , in 2009. Just one company reports on assets, including a line that runs "insurance contracts linked to pensions".

Finally, the greatest amount of information corresponds to the expenditure side, with a maximum of 8 companies in 2008. Nevertheless, this information does not provide an added explanation regarding what should already be found in the notes to the annual accounts, in application of the General Accounting Plan (this being the Royal Decree 1643/1990 until the financial year 2007, or the RD1514/2007 from 2008 onward). Similar to regulations in other European countries, the Spanish regulation provides for the inclusion of information regarding both the average number of employees, and the expenditure breakdown for the Social Charges item, with special reference to allocations and contributions to pension plans, and to the movement of provisions in the balance sheet.

Drawing on the proposal in the Management Commentary guide (IASB, 2005), we observed that when companies provide information on $\mathrm{HC}$ considered as a risk, compliance with the qualitative characteristic of the relevance of information on human capital proves to be inferior than when presenting information on personnel taken as a resource. Our interpretation of this is that companies wish to show only (or preferably) a positive image of what their employees represent for business development. 
Along with some authors who have employed the legitimacy concept for an explanation of narrative disclosure behaviors (Tilling \& Tilt, 2010; Kent \& Zunker, 2013), we highlight that some companies have been involved in labor force adjustment plans and, while from the economic point of view this might be seen as a sign of flexibility and adaptation to new conditions that could be rewarded by investors, it also might be open to other negative interpretations, leading a company to opt for non-disclosure. From an economic viewpoint, investors might also perceive, in the drop in the workforce, confirmation of the difficulties the enterprise is facing, and from a social angle, companies might see their legitimacy jeopardized in view of the fall in net employment in their community.

\section{Conclusions and final reflections}

This study performs a content analysis of HC information disclosed by the top quoted Spanish companies in their Management Report (MR), the aim being to describe the evolution of disclosure behavior after implementation of a new standard in 2005 and taking the recommendations for a high quality Management Commentary (IASB, 2005) as a reference to assess compliance with the qualitative characteristic of the relevance of information disclosed by each company. This longitudinal study obtains evidence that even when a company discloses on an item for a specific financial year, this does not imply that it will do likewise in the future, nor that it will disclose at the same level of fulfillment of the qualitative characteristic of relevance. Further research could assess compliance with other qualitative characteristics required by other standards or guidance.

In any event, while regulatory bodies require that the information disclosed should be of relevance for maximizing its usefulness, companies do not always seem to meet their expectations. In this regard, as recommended by the Report on Accounting Reform in Spain (ICAC, 2002), a compilation has been made of the best identified practices that may act as a guide to other companies.

Finally, we suggest that an internationally accepted agreement must be struck to unite all the efforts that are being made to improve narrative information, whether that be in terms of the annual accounts (FASB, 2012; IFRS Foundation, 2013), and specifically regarding HC and with reference to the MR (IASB, 2010; CNMV, 2013), or even of what has been termed, without having yet been standardized, as Integrated information (IIRC, 2013). 


\section{References}

AN, Y.; DAVEY, H.; EGGLETON, I.R.C. (2011), Towards a comprehensive theoretical framework for voluntary IC disclosure. Journal of Intellectual Capital, 12(4): 571-585. http://dx.doi.org/10.1108/14691931111181733

ARANGUREN, N.; OCHOA, E. (2008). Divulgación de información sobre empleados y medio ambiente en España y Alemania: una nota de investigación. Revista de contabilidad, 11(2): 123-142.

ARCHEL, P. (2003). La divulgación de la información social y medioambiental de la gran empresa española en el periodo 1994-1998: situación actual y perspectivas. Revista Española de Financiación y Contabilidad, 23(117): 571-599.

AX, CH.; MARTON, J. (2008). Human capital disclosures and management practices. Journal of Intellectual Capital, 9(3): 433. http://dx.doi.org/10.1108/14691930810892027

BEATTIE, V.; MCINNES, B.; FEARNLEY, S. (2002). Narrative Reporting by Listed UK Companies: A comparative Within-Sector Topic Analysis. (Last access date: March, 2006). Available online in: http://www.stir.ac.uk/Departments/Management/Accountancy/research/working.htm.

BEATTIE, V.; MCINNES, B.; FEARNLEY, S. (2004). A methodology for analysing and evaluating narratives in annual reports: a comprehensive descriptive profile and metrics for disclosure quality attributes. Accounting Forum, 28: 205-236. http://dx.doi.org/10.1016/j.accfor.2004.07.001

BELLORA, L.; GÜNTHER, T.W. (2013). Drivers of Innovation Capital Disclosure in Intellectual Capital Statements: Evidence from Europe. Innovation Finance \& Accounting eJournal, 1(9): 1. Available online in: http://ssrn.com/asbtract=2055350. (Last access date: February 22th, 2015).

BERETTA, S.; BOZZOLAN, S. (2004). A framework for the analysis of firm risk communication. The International Journal of Accounting, 39: 265-288.

http://dx.doi.org/10.1016/j.intacc.2004.06.006

BOTOSAN, C. (2004). Discussion of A framework for the analysis of firm risk communication. The International Journal of Accounting, 39: 289. http://dx.doi.org/10.1016/j.intacc.2004.06.007

BRONZETTI, G.I.; VELTRI, S. (2013). Intellectual capital reporting in the Italian non-profit sector. A case study analysis. Journal of Intellectual Capital, 14(2): 246-263.

http://dx.doi.org/10.1108/14691931311323878

BUSHEE, B.J. (2004). Discussion of Disclosure practices of Foreign Companies Interacting with U.S. Markets. Journal of Accounting Research, 42(2): 509-525. http://dx.doi.org/10.1111/j.1475679X.2004.00147.x 
CARINI, C.; VENEZIANI, M.; BENDOTTI, G.; TEODORI, C. (2013). Content and quality of information: Analysis of the management discussion session in the Italian financial reports in the period 2003-2008. Corporate Ownership and Control, 10(4CCONT2): 248-264.

CHANDER, S.; MEHRA, V. (2011). A study on intangible assets disclosure: An evidence from Indian companies. Intangible Capital, 7(1):1-30. http://dx.doi.org/10.3926/ic.2011.v7n1.p1-30

CNMV (Comisión Nacional del Mercado de Valores) (2013). Guía para la elaboración del informe de gestión de las entidades cotizadas. Available online in: http://www.cnmv.es/DocPortal/DocFaseConsulta/CNMV/GuiaInformeGestion.pdf

DAVISON, J. (2008). Repetition, rhetoric, reporting and the 'dot.com' era: words, pictures, intangibles. Accounting, auditing and accountability Journal, 21(6): 791-826. http://dx.doi.org/10.1108/09513570810893254

DUMAY, J.; CAI, L. (2014). A review and critique of content analysis as a methodology for inquiring into IC disclosure. Journal of Intellectual Capital, 15(2): 264-290. http://dx.doi.org/10.1108/JIC-01-2014-0010

DUMAY, J.; ROONEY, J. (2011). Measuring for managing?. An IC practice case study. Journal of Intellectual Capital, 12(3): 344-355. http://dx.doi.org/10.1108/14691931111154670

EDVINSSON, L.; MALONE, M.S. (1997). Intellectual Capital: Realizing your company's true value by findings its brainpower. New York, NY: HarperCollins Publishers.

FASB (2012). Invitation to comment. Discussion Paper. Disclosure Framework. 12 July.

FIRTH, M. (1979). The impact of size, stock market listing and auditors on voluntary disclosure in corporate annual reports. Accounting \& Business Research autumn, 9(36): 273-280.

FONTANA, F.; MACAGNAN, C. (2013). Factors explaining the level of voluntary human capital disclosure in the Brazilian capital market. Intangible Capital, 9(1): 305-321.

http://dx.doi.org/10.3926/ic.315

GAMERSCHLAG, R. (2013). Value relevance of human capital information. Journal of Intellectual Capital, 14(2): 325-345. http://dx.doi.org/10.1108/14691931311323913

GAMERSCHLAG, R.; MOELLER, K. (2011). The positive effects of human capital reporting. Corporate Reputation Review, 14(2): 145-155. http://dx.doi.org/10.1057/crr.2011.11

GHANI, W.I.; HAVERTY, J.L. (1998). Market reaction of Multinational corporations to the Passage of the General Agreement on Tariffs and Trade (GATT). Journal of International Accounting, Auditing \& Taxation, 7(1): 95-112. http://dx.doi.org/10.1016/S1061-9518(98)90008-8 
GRANT, R.M. (2004). Contemporary Strategy analysis: concepts, techniques, applications. Malden (MA): Blackwell.

GRAY, R; JAVAD, M.; POWER, D.; SINCLAIR, C.D. (2001). Social and environmental disclosure and corporate characteristics. A research note and extension. Journal of Business Finance \& Accounting, 28(3-4): 327-356. http://dx.doi.org/10.1111/1468-5957.00376

GUTHRIE, J. (2014). In defence of disclosure studies and the use of content analysis: a research note. Journal of Intellectual Capital, 15(2): 5-9. http://dx.doi.org/10.1108/JIC-03-20140029

GUTHRIE, J.; PETTY, R.; YONGVANICH, K.; RICCERI, F. (2004) Using content analysis as a research method to inquire into intellectual capital reporting. Journal of Intellectual Capital, 5(2): 282-293. http://dx.doi.org/10.1108/14691930410533704

HERMANSON, R. (1964). Accounting for human assets. Occasional Paper no 14; East Leasing: Bureau of Business and Economic Research. Michigan State University.

HOLSTI, O.R. (1969). Content analysis for the Social Sciences and Humanities. Reading, MA: Addison Wesley Publishing Company.

HOOKS, J.; COY, D.; DAVEY, H. (2002). The information gap in annual reports. Accounting, Auditing \& Accountability Journal, 15(4):501-522. http://dx.doi.org/10.1108/09513570210440577

IASB (2005). Discussion Paper: Management Commentary. October.

IASB (2010). Project Summary and feedback Statement. Management Commentary. An IFRS Practice Statement. December.

ICAC (Instituto de Contabilidad y Auditoría de Cuentas-Spanish Accounting and Auditing Institute) (2002). Informe sobre la situación actual de la contabilidad en España y líneas básicas para abordar su Reforma (Libro Blanco para la reforma de la contabilidad en España). Madrid: ICAC.

IFRS FOUNDATION (2013). Joint effort needed to tackle disclosure problem. Press release, 24(January): 1-2.

IIRC (International Integrated Reporting Council) (2013). International Integrated Reporting Framework. December, 8th.

JOHANSON, U. (1996). Increasing the transparency of investments in intangibles. Speech to OCDE conference in Chateau Laurier. Otawa, December, 2nd.

JONES, M.; SMITH, M. (2014). Traditional and alternative methods of measuring the understandability of accounting narratives. Accounting, Auditing \& Accountability Journal, 27(1): 183-208. http://dx.doi.org/10.1108/AAAJ-04-2013-1314 
KENT, P.F.; ZUNKER, T. (2013). Attaining Legitimacy by Employee Information in Annual Reports.Accounting, Auditing \& Accountability Journal, 26(7): 1072-1106. http://dx.doi.org/10.1108/AAAJ-03-2013-1261

KNAUER, T. (2010). Relevance, quality and determinants of human capital disclosure -an empirical analysis of the German HDAX companies. Zeitschrift fur Personalforschung, 24(3): 205-230.

KRAVET, T.; MUSLU, V. (2013). Textual risk disclosures and investors' risk perceptions. Review of Accounting Studies, December 18(4): 1088-1122.

LI, F. (2010). Textual analysis of corporate disclosures: a survey of the literature. Journal of accounting literature, 29: 143-165.

LINSLEY, P.; SHRIVES, P.J. (2006). Risk reporting: A study of risk disclosures in the annual reports of UK companies. The British Accounting Review, 38(4): 387-404. http://dx.doi.org/10.1016/j.bar.2006.05.002

LOUGHRAN, T.; MCDONALD, B. (2015). The use of Word lists in textual analysis. Journal of Behavioral Finance, 16(1): 1-11. http://dx.doi.org/10.1080/15427560.2015.1000335

MERITUM (1998). Measuring Intangibles to Understand and Improve Innovation Management. Proposal for a cost-shared RTD project. TSER European Programme. IV Framework Programme.

MERITUM PROJECT (2002). Guidelines for managing and reporting on intangibles. Madrid: Fundación Arital Móvil.

MERKL-DAVIES, D.M.; BRENNAN, N.M. (2011). A conceptual framework of impression management: new insights from psychology, sociology and critical perspectives. Accounting and Business Research, 41(5): 415-437. http://dx.doi.org/10.1080/00014788.2011.574222

PASCUAL, E.; MONEVA, J.M.; FUERTES, Y. (2001), Información de base social en el sector eléctrico español: análisis del contenido y factores explicativos. Cuadernos de economía y dirección de la empresa, 9: 227-248.

PIERROT, F.; SPRING, S. (2010). CSR in the Corporate Discourse: A lexical study of French listed companies. Paper presented at 33 European Accounting Association Congress: 19 May, Istambul, Turquey.

SCHLEICHER, T.; WALKER, M. (2010). Bias in the tone of forward-looking narratives. Accounting and Business Research, 40(4): 371-390. 
SPRINGER, L. (1992). Enhancing the Annual Report: Investor Relations and the MD\&A. The Journal of Bank Accounting \& Auditing, winter, 5(2): 27-31.

STOCK, H. (2003). Poor MD\&A Tops SEC Concern Over Annuals. Investor Relations Business, 10(March): 1 .

SUJAN, A.; ABEYSEKERA, I. (2007). Intellectual Capital Reporting Practices of the Top Australian Firms. Australian Accounting Review, 17(42): 71-83. http://dx.doi.org/10.1111/j.18352561.2007.tb00445.x

SVEIBY, K.E. (1997). The new organizational wealth: managing and measuring knowledgebased assets. San Francisco: Berrett-Koehler Publishers.

TILLING, M.V.; TILT, C.A. (2010). The edge of legitimacy: Voluntary social and environmental reporting in Rothmans' 1956-1999 annual reports. Accounting, Auditing \& Accountability Journal, 23(1): 55-81. http://dx.doi.org/10.1108/09513571011010600

TOO, S.W.; SOMASUNDARAM, N.R. (2011). Determinants of corporate disclosure on intellectual capital in Malaysian IPO prospectuses International. Journal of Learning and Intellectual Capital, 8(4): 418-435. http://dx.doi.org/10.1504/IJLIC.2011.043064

TOWER, G.; PIGNATEL, I.; HAHN, T.; RAJA, A.; RAJA, A. (2010). Transparency of Social and Environmental Disclosures by the Top French Companies. The Journal of Contemporary Issues in Business and Government, 16(1): 26-49.

UNIÓN EUROPEA (2006). RICARDIS reporting intellectual capital to augment research, development and innovation in SMES. Available online in: http://ec.europa.eu/invest-inresearch/pdf/download en/2006-2977 web1.pdf

WYATT, A.; FRICK, H. (2010). Accounting for investments in human capital: A review. Australian Accounting Review, 20(3): 265-273. http://dx.doi.org/10.1111/j.1835-2561.2010.00104.x 